\title{
Advances in methods for detection of anaerobic ammonium oxidizing (anammox) bacteria
}

\author{
Meng Li • Ji-Dong Gu
}

Received: 31 January 2011 /Revised: 28 February 2011 / Accepted: 1 March 2011 /Published online: 8 April 2011

(C) The Author(s) 2011. This article is published with open access at Springerlink.com

\begin{abstract}
Anaerobic ammonium oxidation (anammox), the biochemical process oxidizing ammonium into dinitrogen gas using nitrite as an electron acceptor, has only been recognized for its significant role in the global nitrogen cycle not long ago, and its ubiquitous distribution in a wide range of environments has changed our knowledge about the contributors to the global nitrogen cycle. Currently, several groups of methods are used in detection of anammox bacteria based on their physiological and biochemical characteristics, cellular chemical composition, and both 16S rRNA gene and selective functional genes as biomarkers, including hydrazine oxidoreductase and nitrite reductase encoding genes hzo and nirS, respectively. Results from these methods coupling with advances in quantitative PCR, reverse transcription of mRNA genes and stable isotope labeling have improved our understanding on the distribution, diversity, and activity of anammox bacteria in different environments both natural and engineered ones. In this review, we summarize these methods used in detection of anammox bacteria from various environments, highlight the strengths and weakness of these methods, and also discuss the new development potentials on the existing and new techniques in the future.
\end{abstract}

Electronic supplementary material The online version of this article (doi:10.1007/s00253-011-3230-6) contains supplementary material, which is available to authorized users.

M. Li $\cdot$ J.-D. Gu $(\bowtie)$

Laboratory of Environmental Microbiology and Toxicology,

School of Biological Sciences, The University of Hong Kong,

Pokfulam Road,

Hong Kong, SAR, People's Republic of China

e-mail: jdgu@hkucc.hku.hk

J.-D. Gu

The Swire Institute of Marine Science,

The University of Hong Kong,

Shek O, Cape d'Aguilar,

Hong Kong, SAR, People's Republic of China
Keywords Anammox bacteria - Isotope pairing technique . Lipid analysis - Molecular technique $16 \mathrm{~S}$ rRNA gene . Functional biomarkers

\section{Introduction}

Anaerobic ammonium oxidation (anammox) is a newly discovered biochemical pathway involved in the microbial $\mathrm{N}$ cycle that allows coupling between ammonium oxidation with nitrite reduction under anoxic conditions (van de Graaf et al. 1995). Since then, the applications of anammox in the removal of inorganic $\mathrm{N}$ species from wastewater with high ammonium concentrations had resulted in new innovations in wastewater treatments, such as combining anammox with nitrification process in a single reaction system for high ammonium removal over nitrite (Hellinga et al. 1998), completely autotrophic $\mathrm{N}$ removal over nitrite (Sliekers et al. 2002) or oxygen-limited ammonium removal via nitrification-denitrification (Kuai and Verstraete 1998), and short-cut nitrification and denitrification (Kumar and Lin 2010). However, the first anammox bacterium named Candidatus "Brocadia anammoxidans" was firstly physically separated from a laboratory enrichment culture in bioreactor using a Percoll gradient centrifugation (Strous et al. 1999) and they display complex cellular architectures and chemical composition, including a central cellular compartment anammoxosome where the biochemical anammox process is proposed to take place and the unique ladderane lipids in the membrane (Strous et al. 1999). So far, only five anammox genera have been recognized (Fig. 1), namely Kuenenia (Schmid et al. 2000; Strous et al. 2006), Brocadia (Strous et al. 1999; Kartal et al. 2008), Anammoxoglobus (Kartal et al. 2007b), Jettenia (Quan et al. 2008), and Scalindua (Kuypers et al. 2003; van de Vossenberg et al. 2008; Hong et al. 2011).

While researches on the applications of anammox bacteria and their related basic biology and biochemistry have provided 
Fig. 1 A phylogenetic tree of described anammox bacteria species based their 16S rRNA genes. Phylogenetic tree was constructed by MEGA 4.0 with 1,000 times bootstraps, and the scale bar represents $5 \%$ sequence divergence

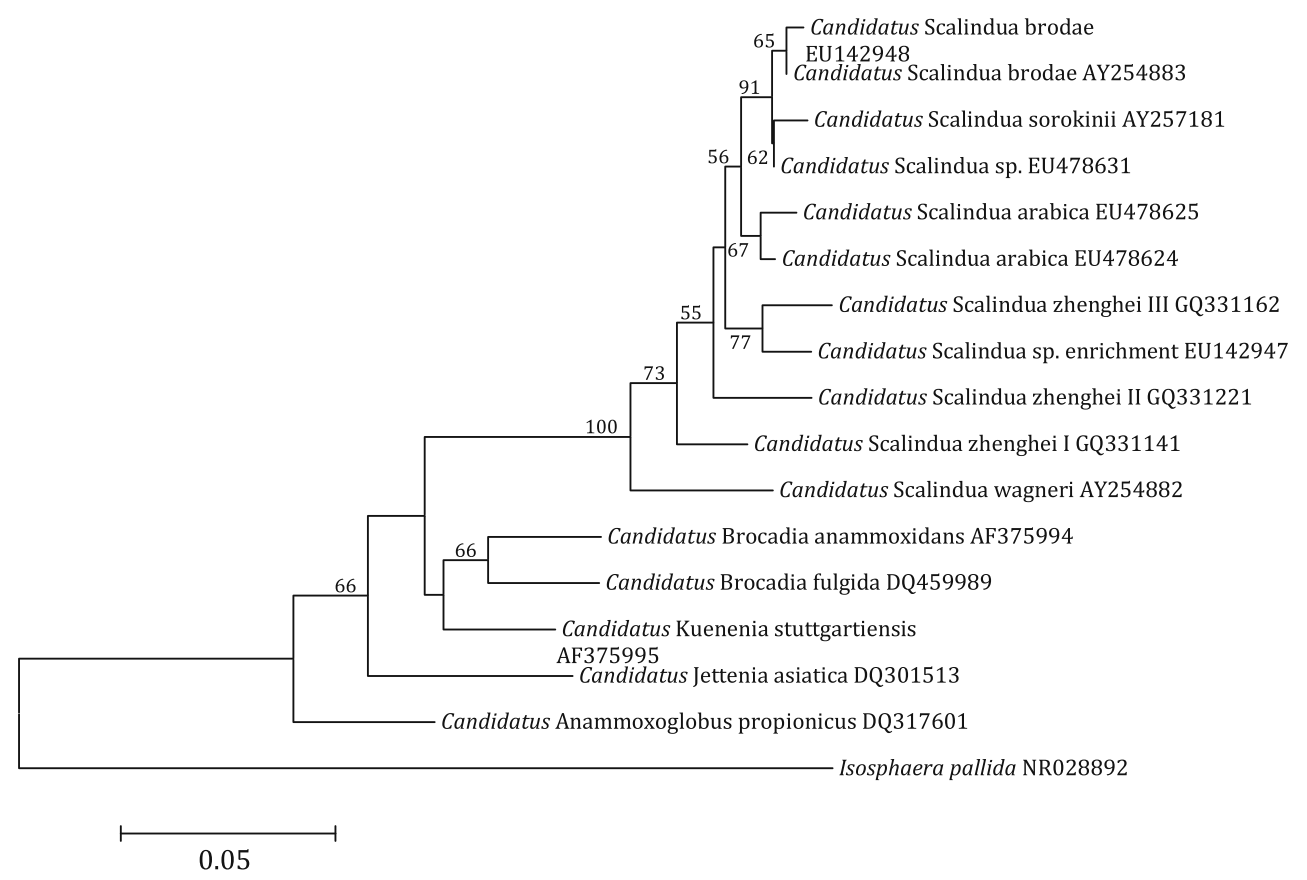

fascinating new biological information, observations made from both field and laboratory investigations have also indicated that the anammox process is a key one only recognized recently in the global $\mathrm{N}$ cycle (Francis et al. 2007). It has been estimated that this process alone is likely responsible for the consumption of more than $40 \%$ of the fixed $\mathrm{N}$ assimilated into the anoxic Black Sea (Kuypers et al. 2003), 19-35\% of the total $\mathrm{N}_{2}$ evolved in the anoxic water column of the coastal bay in Costa Rica (Dalsgaard et al. 2003), $24-67 \%$ of the total $\mathrm{N}_{2}$ production in continental shelf sediments (Dalsgaard and Thamdrup 2002), and 1-24\% of the $\mathrm{N}$ loss in estuarine sediments (Trimmer et al. 2003; Risgaard-Petersen et al. 2004). In a global context, anammox reaction may thus account for $30-70 \%$ of oceanic $\mathrm{N}_{2}$ production, which fundamentally changes our traditional view on that denitrification is the only major $\mathrm{N}$ sink in the marine ecosystems (Devol 2003). Up to now, anammox process has been demonstrated in very diverse environments, including the suboxic and oxygen minimum zones of oceans (Kuypers et al. 2003, 2005), surface and subsurface sediments of deep ocean (Hong et al. 2011; Li et al. 2010b), temperate estuarine, coastal and offshore sediments (Jetten et al. 2003; Li et al. 2010b; Tal et al. 2005; Trimmer et al. 2005), lakes (Schubert et al. 2006), freshwaters (Penton et al. 2006), polar region sediments and multiyear sea ice (Rysgaard and Glud 2004; Rysgaard et al. 2004), oil reservoirs (Li et al. 2010a), and deep-sea hydrothermal vent (Byrne et al. 2009).

In the last decade of anammox research, three main categories of approaches were used to detect anammox bacteria in natural environments and wastewater treatment systems: activity measurements by the isotope pairing technique (IPT), analysis of anammox bacteria-specific lipids, and a suite of molecular techniques from PCR amplification to quantitative PCR and reverse-transcription (RT)-PCR of anammox bacterial gene biomarkers. Several previous reviews had discussed the detection methods for anammox bacteria so far (Jetten et al. 2005, 2009; Schmid et al. 2005; Junier et al. 2010; Kartal et al. 2011), and the information improved our general understanding on distribution of anammox bacteria in various niches. However, due to the rapid advances in anammox bacteria research in recent years, especially on more in-depth information about phylogenetic groups, metabolic capability, and physiology and evolution, we would like to give an updated and collated information on methods available in detection of anammox bacteria in both environmental samples and laboratory enrichments, their strengths and drawbacks, and the future development potentials with new emerging functional gene biomarkers in the present review.

\section{Isotope pairing technique}

IPT is a well-established ${ }^{15} \mathrm{~N}$ method used in estimation of denitrification (Nielsen 1992) on many environmental samples, such as marine sediments, lake sediments, rivers, and wetland (Rysgaard et al. 1993; Stepanauskas et al. 1996; Davidsson et al. 1997; Pind et al. 1997; Dong and Tollner 2003; Trimmer et al. 2003). In 2002, IPT was used to estimate the relative contribution of anammox process to the overall total $\mathrm{N}_{2}$ production through coupling with nitrate reduction in marine sediment (Thamdrup and Dalsgaard 2002). Risgaard-Petersen et al. (2003) described the detail methodology for application of IPT in sediments where anammox and denitrification coexist. Experimental 
samples can be treated for a short-term incubation (e.g., $24 \mathrm{~h}$ ) in parallel with different inorganic ${ }^{15} \mathrm{~N}$ species labeled substrates: (1) ${ }^{15} \mathrm{NH}_{4}^{+}$alone, (2) a mixture of ${ }^{15} \mathrm{NH}_{4}^{+}$and ${ }^{14} \mathrm{NO}_{2}{ }^{-}$, and (3) ${ }^{15} \mathrm{NO}_{2}{ }^{-}$alone. After incubation, $\mathrm{N}_{2}$ production from each treatment can be collected and measured on an isotope mass spectrometer for ${ }^{15} \mathrm{~N}$ concentrations. The first incubation is used as a control to detect any oxidation of ammonium without the addition of nitrite, while the second treatment is used to measure the anammox activity, where the production of ${ }^{29} \mathrm{~N}_{2}$ stoichiometrically is a confirmation on the oxidation of ammonium $\left({ }^{15} \mathrm{NH}_{4}{ }^{+}\right)$ with reduction of nitrite $\left({ }^{14} \mathrm{NO}_{2}{ }^{-}\right)$through the anammox process. The third incubation is to estimate the relative contribution of anammox and denitrification collectively, where the production of ${ }^{29} \mathrm{~N}_{2}$ and ${ }^{30} \mathrm{~N}_{2}$ indicate the activities of anammox and denitrification, respectively (Risgaard-Petersen 2003; Dalsgaard et al. 2003, 2005). Experimental details of the IPT procedures for the measurement of anammox and denitrification were described by Risgaard-Petersen et al. (2003) and further modifications had been made by Ward et al. (2009). Up to now, IPT has been used as the widely accepted method to substantiate the contribution of anammox process in various environmental samples. However, new evidences had pointed out that anammox bacteria could also reduce ${ }^{15} \mathrm{NO}_{3}{ }^{-}$to ${ }^{15} \mathrm{NO}_{2}{ }^{-}$and then to ${ }^{15} \mathrm{NH}_{4}{ }^{+}$under certain conditions and as a result, portions of the measured denitrification may be partitioned to the anammox reaction (Kartal et al. 2007a). In addition, IPT provides indisputable information on the specific process involved, but neither abundance nor the organisms responsible for the anammox process is available (Schmid et al. 2005).

Another isotope-labeling technique for detection the presence and activity of anammox bacteria is stable isotope probing (SIP) with ${ }^{13} \mathrm{CO}_{2}$ and/or ${ }^{15} \mathrm{~N}$ labeled inorganic $\mathrm{N}$ species. SIP is a powerful technique when combined with current available molecular methods in revealing the anammox community composition and the associated microbial activity in environmental samples (Murrell and Whiteley 2011). This method relies on the incorporation of a substrate that is preferably enriched in a heavier stable isotope, such as ${ }^{13} \mathrm{C}$ or/and ${ }^{15} \mathrm{~N}$ which allows the identification of an active population of microorganisms through selective recovery and analysis of isotope-enriched cellular biomolecules, such as DNA, RNA, proteins, and phosphorus lipid fatty acids (Bull et al. 2000; Murrell and Whiteley 2011). Currently, SIP has been successfully applied in the study of microbial nitrogen cycle, e.g., ammonia-oxidizing archaea and bacteria in the soils (Tourna et al. 2010; Zhang et al. 2011; Pratscher et al. 2011). In these studies, ${ }^{13} \mathrm{CO}_{2}$ and ${ }^{14} \mathrm{~N} /{ }^{15} \mathrm{~N}$ were used as substrates for microbial metabolism in the soil samples, and then total DNA, RNA, or mRNA were extracted after a period of incubation for analysis of the relevant microbial communities and microbial abundance using relevant molecular techniques could be obtained for direct evidence on the active microbial groups and their abundance (Tourna et al. 2010; Zhang et al. 2011). In research on anammox bacteria, ${ }^{14} \mathrm{C}$ labeled substrates were also used for fluorescence in situ hybridization (FISH)-microautoradiography analysis to confirm the chemolithoautotrophic biochemical pathway carried out by anammox bacteria (Strous et al. 1998; Jetten et al. 2002), and no other related reports are available. Therefore, SIP coupling with an array of molecular techniques (see below) is a promising approach for detection and quantification of anammox bacteria in the ecosystem.

\section{Lipid measurement}

In contrast to all other known prokaryotes, anammox bacteria have special lipids in cellular membrane surrounding the anammoxosome within the anammox bacterial cells (Sinninghe Damste et al. 2002). These membrane ladderane lipids contain cyclobutane/cyclohexane ring systems, which make the anammoxosome membrane very impermeable comparing to other known non-annamox bacterial membranes (Sinninghe Damste et al. 2002; van Niftrik et al. 2004). Since the unique lipids are only found in anammox bacteria so far, the ladderane lipid can be used as an indicator and a biomarker for the presence of anammox bacteria in environmental samples (Sinninghe Damste et al. 2002, 2005; Kuypers et al. 2003). Furthermore, ladderane lipids are predominately enumerated as the core lipid derivatives (Kuypers et al. 2003, 2005; Jaeschke et al. 2007), but occurring as intact ladderane glycerophospholipids (ladderane IGPs) within cells at high abundances (Boumann et al. 2006), thus the ladderane IGPs, such as C20-[3]-ladderane monoalkylether-phosphocholine, may reflect living biomass more accurately than ladderane core lipids. Because of this, they are more specific biomarkers for viable anammox bacteria (Jaeschke et al. 2009). Up to now, the detection and quantification of ladderane lipids are used not only to infer the presence of anammox bacteria in environmental samples (Strous et al. 1999; Sinninghe Damste et al. 2002, 2005), but also to assess the presence of anammox bacteria associated with some of the geological events (Jaeschke et al. 2007).

In order to analyze ladderane lipids, biomass containing anammox bacteria are firstly extracted with methanol, methanol/dichloromethane, and dichloromethane substantially. The extracts are methylated with B3/methanol after removing the solvent by a rotary evaporator, and then fractionated by a small silica column using ethyl acetate as the eluent. After that, the obtained fraction is silylated with BSTFA in pyridine convert alcohols in TMS ethers for 
further analysis by gas chromatography (GC) and gas chromatography/mass spectrometry (GC/MS)(Sinninghe Damste et al. 2002). Various chemicals contained in the ladderane lipids, such as fatty acids, glycerol diethers, glycerol ether-esters, and $s n-2$ glycerol monoether, would be analyzed through these procedures (Sinninghe Damste et al. 2002, 2005). Recently, a high performance liquid chromatography/atmospheric pressure chemical ionizationMS/MS method allowing determination of low levels of ladderane lipids in complex matrixes (e.g., sediments) had been developed with success, and this technique could detect as low as about 35 pg ladderane lipids, which improves the method resolution compared to the GC/MS method greatly (Hopmans et al. 2006). Although the lipids analysis provides a powerful tool to detect anammox bacteria, the following deficiencies still exist when using this technique on environmental samples: (1) extraction procedures are complicated; (2) high volume of samples is required, such as the seawaters and sediment due to the low abundance of anammox bacteria; (3) difficulties are encountered in purification when dealing with sediment materials because of other contaminants, such as humic acid and fulvic acid; and (4) these lipids may also be present in nonliving organic matter and thus may not necessarily indicate the presence of metabolically active anammox bacteria without error (Schmid et al. 2005), which limits the quantification of active anammox bacteria population with high confidence and precision.

\section{Molecular techniques}

Since anammox bacteria have not been isolated in pure culture, culture-independent methods, specifically DNA/ RNA-based molecular techniques, are the most widely used approaches available for detecting this group of microorganisms in various samples (Schmid et al. 2005). For molecular techniques, the available techniques include FISH-based techniques, PCR-based methods and quantification by quantitative PCR (qPCR) and RT-qPCR.

\section{FISH-based technique}

FISH is a useful tool for cultivation independent in situ identification of targeted cells in environmental samples. Many investigations have used the FISH technique to collect both qualitative and quantitative data on anammox bacteria in environmental samples (Schmid et al. 2005). For this widely used technique on anammox bacteria, previous research has mainly focused on the followings.

First, the research focus is on design-specific oligonucleotide probes for anammox bacteria detection. Because different probes may specifically target different groups of microorganisms, specificity of fluorochrome-labeled DNA oligonucleotide probe is one of the most important factors for successful application of this technique in practice (Giovannoni et al. 1988; Amann et al. 1990). To detect anammox bacteria, a number of probes are available for different genus/species of anammox bacteria, and a summary of the representatives and widely used probes for different genera of anammox bacteria are shown in Table 1 . Most of the available probes used in FISH detection target the 16S rRNA genes of anammox bacteria, but probe for 23S rRNA gene has also been developed, such as the L-*Amx-1900-a-A-21 (Schmid et al. 2001), and it is feasible that more specific probes will become available for anammox bacteria detection along with the fast research progress made in genomic data of anammox bacteria available currently and in the near future. However, the high divergence $(<87.1 \%$ similarity $)$ among different genera of anammox bacteria often impedes the discovery of new anammox species (Schmid et al. 2003; Jetten et al. 2009). Thus, it is essential to re-evaluate the anammoxspecific probe sets available so that new probes can be used for more effective revealing of new anammox species from the environment.

Second, FISH technique can be used to quantify the abundance of anammox bacteria. FISH with specific oligonucleotide probes is the standard technique to quantify the abundance of targeted anammox bacteria in environmental samples (Kuypers et al. 2003; Risgaard-Petersen et al. 2004; Schmid et al. 2000, 2003). Up to now, FISH technique has been widely used to assess the abundance of anammox bacteria in various environmental samples, which has provided a quantitative distribution of anammox bacteria globally (Schmid et al. 2007; Zhu et al. 2010). However, it is often hampered by its detection limit $(1,000$ cells $/ \mathrm{ml}$ seawater) or various interferences from the matrix of environmental samples (Kuypers et al. 2003; Pavlekovic et al. 2009). To overcome these limitations, different strategies have been used to optimize the FISH procedures for quantitatively detect anammox bacteria, such as increasing the probe signal intensity by polynucleotide FISH (Zwirglmaier 2005) and catalyzed reported deposition FISH (CARD-FISH) (Pernthaler et al. 2002; Hoshino et al. 2008), or minimizing probe penetration problems and increasing hybridization efficiencies with different probes chemistries, like peptide nucleic acid FISH (Perry-O'Keefe et al. 2001) and locked nucleic acid FISH (Kubota et al. 2006).

Thirdly, integration of FISH with other experiment approaches to gain more insights into the metabolic activity of anammox bacteria and extends the applications of FISH as a powerful technique. The first approach discussed above is to target the intergenic spacer region (ISR) between $16 \mathrm{~S}$ and $23 \mathrm{~S}$ rRNA genes by FISH. In general, 
Table 1 A list of commonly used probes in identifying known anammox bacteria with probe sequences, target genes, and formamide required for specific FISH technique

\begin{tabular}{|c|c|c|c|c|c|}
\hline Name of probes & Sequence $5^{\prime}-3^{\prime}$ & $\begin{array}{l}\text { Targeted } \\
\text { gene }\end{array}$ & Specificity group & $\begin{array}{l}\text { Formamide (\%)/ } \\
\mathrm{mM} \mathrm{NaCl}\end{array}$ & References \\
\hline $\begin{array}{l}\text { S-P-Planc-0046-a-A- } \\
\quad 18\end{array}$ & GACTTGCATGCCTAATCC & $\begin{array}{l}\text { 16S } \\
\text { rRNA }\end{array}$ & Planctomycetes & $25 / 159$ & $\begin{array}{l}\text { Neef et al. } \\
\quad(1998)\end{array}$ \\
\hline $\begin{array}{l}\text { S-P-Planc-0886-a- } \\
\quad \text { A-19 }\end{array}$ & GCCTTGCGACCATACTCCC & $\begin{array}{l}16 \mathrm{~S} \\
\text { rRNA }\end{array}$ & Isosphaera, Gemmata, Pirellula, Planctomycetales & $30 / 112$ & $\begin{array}{l}\text { Neef et al. } \\
\text { (1998) }\end{array}$ \\
\hline $\begin{array}{l}\text { S-D-Bact-0338-b-A- } \\
18\end{array}$ & GCAGCCACCCGTAGGTGT & $\begin{array}{l}16 \mathrm{~S} \\
\text { rRNA }\end{array}$ & $\begin{array}{l}\text { Specific for Planctomycetales and to be used in } \\
\text { combination with EUBI and III }\end{array}$ & $0 / 900$ & $\begin{array}{l}\text { Daims et al. } \\
\text { (1999) }\end{array}$ \\
\hline S-*-Amx-0368-a-A-18 & CCTTTCGGGCATTGCGAA & $\begin{array}{l}16 \mathrm{~S} \\
\text { rRNA }\end{array}$ & All anammox organisms & $15 / 338$ & $\begin{array}{l}\text { Schmid et al. } \\
\text { (2003) }\end{array}$ \\
\hline S-*-Amx-0820-a-A-22 & AAAACCCCTCTACTTAGTGCCC & $\begin{array}{l}16 \mathrm{~S} \\
\text { rRNA }\end{array}$ & Brocadia anammoxidans Kuenenia stuttgartiensis & $40 / 56$ & $\begin{array}{l}\text { Schmid et al. } \\
\text { (2000) }\end{array}$ \\
\hline S-G-Sca-1309-a-A-21 & TGGAGGCGAATTTCAGCCTCC & $\begin{array}{l}16 \mathrm{~S} \\
\text { rRNA }\end{array}$ & Scalindua & $5 / 675$ & $\begin{array}{l}\text { Schmid et al. } \\
\text { (2003) }\end{array}$ \\
\hline $\begin{array}{l}\text { S-*-Scabr-1114-a-A- } \\
22\end{array}$ & CCCGCTGGTAACTAAAAACAAG & $\begin{array}{l}16 \mathrm{~S} \\
\text { rRNA }\end{array}$ & Scalindua brodae & $20 / 225$ & $\begin{array}{l}\text { Schmid et al. } \\
\text { (2003) }\end{array}$ \\
\hline S-*-BS-820-a-A-22 & TAATTCCCTCTACTTAGTGCCC & $\begin{array}{l}16 \mathrm{~S} \\
\text { rRNA }\end{array}$ & $\begin{array}{l}\text { Scalindua wagneri } \\
\text { Scalindua sorokinii }\end{array}$ & $40 / 56$ & $\begin{array}{l}\text { Kuypers et al. } \\
(2003)\end{array}$ \\
\hline S-S-Kst-0157-a-A-18 & GTTCCGATTGCTCGAAAC & $\begin{array}{l}16 \mathrm{~S} \\
\text { rRNA }\end{array}$ & Kuenenia stuttgartiensis & $25 / 159$ & $\begin{array}{l}\text { Schmid et al. } \\
\text { (2001) }\end{array}$ \\
\hline S-*-Kst-1275-a-A-20 & TCGGCTTTATAGGTTTCGCA & $\begin{array}{l}16 \mathrm{~S} \\
\text { rRNA }\end{array}$ & Kuenenia stuttgartiensis & $25 / 159$ & $\begin{array}{l}\text { Schmid et al. } \\
\quad(2000)\end{array}$ \\
\hline $\begin{array}{c}\text { S-S-Ban-0162(B. } \\
\text { anam.)-a-A-18 }\end{array}$ & CGGTAGCCCCAATTGCTT & $\begin{array}{l}16 \mathrm{~S} \\
\text { rRNA }\end{array}$ & Brocadia anammoxidans & $40 / 56$ & $\begin{array}{l}\text { Schmid et al. } \\
(2000)\end{array}$ \\
\hline S-*-Amx-0156-a-A-18 & CGGTAGCCCCAATTGCTT & $\begin{array}{l}16 \mathrm{~S} \\
\text { rRNA }\end{array}$ & Brocadia anammoxidans & $40 / 56$ & $\begin{array}{l}\text { Schmid et al. } \\
\text { (2000) }\end{array}$ \\
\hline S-*-Amx-0223-a-A-18 & GACATTGACCCCTCTCTG & $\begin{array}{l}16 \mathrm{~S} \\
\text { rRNA }\end{array}$ & Brocadia anammoxidans & $40 / 56$ & $\begin{array}{l}\text { Schmid et al. } \\
\text { (2000) }\end{array}$ \\
\hline S-*-Amx-0432-a-A-18 & CTTAACTCCCGACAGTGG & $\begin{array}{l}16 \mathrm{~S} \\
\text { rRNA }\end{array}$ & Brocadia anammoxidans & $40 / 56$ & $\begin{array}{l}\text { Schmid et al. } \\
\text { (2000) }\end{array}$ \\
\hline S-*-Amx-0613-a-A-22 & CCGCCATTCTTCCGTTAAGCGG & $\begin{array}{l}16 \mathrm{~S} \\
\text { rRNA }\end{array}$ & Brocadia anammoxidans & $40 / 56$ & $\begin{array}{l}\text { Schmid et al. } \\
\text { (2000) }\end{array}$ \\
\hline S-*-Amx-0997-a-A-21 & TTTCAGGTTTCTACTTCTACC & $\begin{array}{l}16 \mathrm{~S} \\
\text { rRNA }\end{array}$ & Brocadia anammoxidans & $20 / 225$ & $\begin{array}{l}\text { Schmid et al. } \\
\text { (2000) }\end{array}$ \\
\hline S-*-Amx-1015-a-A-18 & GATACCGTTCGTCGCCCT & $\begin{array}{l}16 \mathrm{~S} \\
\text { rRNA }\end{array}$ & Brocadia anammoxidans & $60 / 14$ & $\begin{array}{l}\text { Schmid et al. } \\
\text { (2000) }\end{array}$ \\
\hline S-*-Amx-1154-a-A-18 & TCTTGACGACAGCAGTCT & $\begin{array}{l}16 \mathrm{~S} \\
\text { rRNA }\end{array}$ & Brocadia anammoxidans & $20 / 225$ & $\begin{array}{l}\text { Schmid et al. } \\
\text { (2000) }\end{array}$ \\
\hline S-*-Amx-1240-a-A-23 & TTTAGCATCCCTTTGTACCAACC & $\begin{array}{l}16 \mathrm{~S} \\
\text { rRNA }\end{array}$ & Brocadia anammoxidans & $60 / 14$ & $\begin{array}{l}\text { Schmid et al. } \\
\quad(2000)\end{array}$ \\
\hline S-*-Bfu-0613-a-A-24 & GGATGCCGTTCTTCCGTTAAGCGG & $\begin{array}{l}16 \mathrm{~S} \\
\text { rRNA }\end{array}$ & Brocadia fulgida & $30 / 112$ & $\begin{array}{l}\text { Kartal et al. } \\
\qquad(2008)\end{array}$ \\
\hline S-*-Apr-0820-a-A-21 & AAACCCCTCTACCGAGTGCCC & $\begin{array}{l}16 \mathrm{~S} \\
\text { rRNA }\end{array}$ & $\begin{array}{l}\text { Anammoxoglobus propionicus } \\
\text { Jettnia asiatica }\end{array}$ & $40 / 56$ & $\begin{array}{l}\text { Kartal et al. } \\
\text { (2007b) }\end{array}$ \\
\hline $\begin{array}{l}\text { L-*-Amx-1900-a-A- } \\
\quad 21\end{array}$ & CATCTCCGGCTTGAACAA & $\begin{array}{l}23 \mathrm{~S} \\
\text { rRNA }\end{array}$ & Brocadia and Kuenenia & $30 / 112$ & $\begin{array}{l}\text { Schmid et al. } \\
\text { (2001) }\end{array}$ \\
\hline $\begin{array}{l}\text { I-*-Ban-0071(B. } \\
\text { anam.)-a-A-18 }\end{array}$ & CCCTACCACAAACCTCGT & ISR & Brocadia anammoxidans & $10 / 450$ & $\begin{array}{l}\text { Schmid et al. } \\
\text { (2000) }\end{array}$ \\
\hline $\begin{array}{l}\text { I-*-Ban-0108(B. } \\
\text { anam. }) \text {-a-A-18 }\end{array}$ & TTTGGGCCCGCAATCTCA & ISR & Brocadia anammoxidans & $10 / 450$ & $\begin{array}{l}\text { Schmid et al. } \\
\text { (2000) }\end{array}$ \\
\hline $\begin{array}{r}\text { I-*-Ban-0222(B. } \\
\text { anam.)-a-A-19 }\end{array}$ & GCTTAGAATCTTCTGAGGG & ISR & Brocadia anammoxidans & $10 / 450$ & $\begin{array}{l}\text { Schmid et al. } \\
\text { (2000) }\end{array}$ \\
\hline $\begin{array}{l}\text { I-*-Ban-0389(B. } \\
\text { anam.)-a-A-18 }\end{array}$ & GGATCAAATTGCTACCCG & ISR & Brocadia anammoxidans & $10 / 450$ & $\begin{array}{l}\text { Schmid et al. } \\
\text { (2000) }\end{array}$ \\
\hline $\begin{array}{l}\text { I-*-Kst-0031(K.stutt.)- } \\
\text { a-A-18 }\end{array}$ & ATAGAAGCCTTTTGCGCG & ISR & Kuenenia stuttgartiensis & $10 / 450$ & $\begin{array}{l}\text { Schmid et al. } \\
\text { (2001) }\end{array}$ \\
\hline $\begin{array}{l}\text { I-*-Kst-0077(K.stutt.)- } \\
\text { a-A-18 }\end{array}$ & TTTGGGCCACACTCTGTT & ISR & Kuenenia stuttgartiensis & $10 / 450$ & $\begin{array}{l}\text { Schmid et al. } \\
\text { (2001) }\end{array}$ \\
\hline $\begin{array}{l}\text { I-*-Kst-0193(K.stutt.)- } \\
\text { a-A-19 }\end{array}$ & CAGACCGGACGTATAAAAG & ISR & Kuenenia stuttgartiensis & $10 / 450$ & $\begin{array}{l}\text { Schmid et al. } \\
\text { (2001) }\end{array}$ \\
\hline $\begin{array}{l}\text { I-*-Kst-0288(K.stutt.)- } \\
\text { a-A-20 }\end{array}$ & GCGCAAAGAAATCAAACTGG & ISR & Kuenenia stuttgartiensis & $10 / 450$ & $\begin{array}{l}\text { Schmid et al. } \\
\text { (2001) }\end{array}$ \\
\hline
\end{tabular}


the classical FISH as outlined to deliver both qualitative and quantitative data about the bacterial or archaeal population in a sample and the FISH intensity can also be used to assess their activity for many fast-growing microorganisms (Poulsen et al. 1993). However, the ribosome contents do not decrease significantly for betaproteobacterial ammonia-oxidizing bacteria and anammox bacteria during the period of starvation (Morgenroth et al. 2000) or inhibition (Schmid et al. 2001; Wagner et al. 1995). To learn more about the in situ activity of anammox bacteria, the ISR bewteen $16 \mathrm{~S}$ and $23 \mathrm{~S}$ rRNA genes has been targeted with fluorescent-labeled oligonucleotide probes, and quantitative FISH experiments with cells of Candidatus "Brocadia anammoxidans" that were inhibited by exposure to oxygen for different time periods demonstrated that the concentration of transcribed ISR reflected the activity of the cells more accurately than the $16 \mathrm{~S}$ or $23 \mathrm{~S}$ rRNA concentration (Schmid et al. 2001). Results have also shown that the ISR-targeted FISH (ISR-FISH) has great potential in monitoring activity changes in enrichment cultures of anammox bacteria and ecosystems (Third et al. 2001; Schmid et al. 2005). However, one disadvantage associated with this technique is that the ISR sequence lack evolutionary pressure, which might result in two strains of the same species show sequences very different. In addition, only two sets of ISR probes available for Candidatus "Kuenenia stuttgartiensis" and Candidatus "Brocadia anammoxidans" limit the application of ISR-FISH currently, indicating that more new probes need to be designed for wider applications of this technique (Table 1). The second category of methods using FISH in determining the metabolic activity of anammox bacteria is to combine the classical FISH with microautoradiography (FISH-MAR). The FISH-MAR has been developed more than 10 years ago, and it links to the uptake of radiolabeled substrates, such as $\left[{ }^{14} \mathrm{C}\right]$ acetate, $\left[{ }^{14} \mathrm{C}\right]$ butyrate, $\left[{ }^{14} \mathrm{C}\right]$ bicarbonate, and ${ }^{33} \mathrm{P}_{\mathrm{i}}$, with specific organisms in a complex environmental sample, and it provides a unique approach for obtaining insights into the microbial community structures and functions simultaneously (Lee et al. 1999). For detection of anammox bacteria, FISH-MAR with the radiolabeled ${ }^{14} \mathrm{CO}_{2}$ is very meaningful in demonstrating the chemolithoautotrophic pathway active in anammox bacteria (Strous et al. 1998; Jetten et al. 2002). In the co-cultures of aerobic and anaerobic ammonium oxidizers, FISH-MAR is also successfully used to measure the uptake of ${ }^{14} \mathrm{CO}_{2}$ (Schmid et al. 2005). Although FISH-MAR can be applied successfully in anammox bacteria detection with insights of their function, a longer incubation time is necessary for sufficient incorporation of the labeled substrate, which might not always reflect the physiological state of anammox bacteria at in situ condition and/or at the time of sampling (Schmid et al. 2005). The third category of methods for obtaining insights into the microbial community structures and functions by FISH technique is the gene-FISH (Moraru et al. 2010). This method is to relate the presence of functional gene with cell identity in the samples, and the signals can be visualized at a single cell level. This protocol, when combined with rRNA gene and in situ functional gene detections targeted by CARD-FISH, has identified that at least $30 \%$ the marine Crenarchaeota in the Benguela upwelling system harbored the amoA genes, providing stronger evidences for the important role of Crenarchaea in nitrification (Moraru et al. 2010). However, no related research has been reported and thus further efforts are needed to extend this new technique for detection of anammox bacteria in various environmental systems.

Briefly, although the experimental procedures for higher resolution and elimination of the interferences from sample matrix are still needed to improve the performance of detection methods in a wide range of environment samples and the better anammox-specific probe sets are also required for further specific evaluation, FISH has been proven a powerful technique for environmental detection of anammox bacteria, which not only obtains the qualitative and quantitative basic information, but also provides new insights into the metabolic activity of anammox bacteria.

\section{PCR-based technique}

In environmental samples, PCR amplification of sample DNA templates with specific biomarkers specific primers and subsequent phylogenetic analysis of the amplified DNA products is the method of choice to detect any previously unknown microorganisms (Amann et al. 1995). In the anammox case, this method is the most widely used and has successfully identified the presence of anammox bacteria in a wide range of samples. In addition to the commonly used 16S rRNA gene, additional gene biomarkers associated with metabolic reactions for anammox bacteria detection via PCR amplification have also been reported.

\section{S rRNA gene}

The most commonly used phylogenetic biomarker for studying microbial communities is the 16S rRNA gene. According to available information, 16S rRNA gene sequence analyses have shown that all known anammox bacteria form a monophyletic clade within the phylum Planctomycetes (Kuenen 2008). Most of the studies so far for detecting anammox bacteria in natural assemblages are often based on 16S rRNA genes (Kuenen 2008; Jetten et al. 2009); however, the initial difficulty in detection of anammox bacteria with PCR method is that anammox bacterial $16 \mathrm{~S}$ rRNA genes are not amplified very well with the universal 
bacterial primers (Schmid et al. 2005; Li et al. 2010b). This is due to a high 16S rRNA gene sequence divergence that occurs among different genera of anammox bacteria $(<87.1 \%$ identity), and there are no general PCR primers for different genera of anammox bacteria (Jetten et al. 2009; Junier et al. 2010), especially in some environments where anammox bacteria constitute only a very small fraction $(<1 \%)$ of the whole community population (Kartal et al. 2011). Selective PCR primer sets intended for anammox bacteria from natural environment have very low specificity; as a result, nonanammox bacteria, such as Vibrio species, can be amplified from coastal marine sediment (Fig. S1). The available data have shown that there are also many PCR primers with high specificity to target different genera of anammox bacteria, providing ample information about the presence of anammox bacteria from phylogenetic diversity to the community structures and to the quantitative distribution in various environments. A summary of the widely used PCR primers and their optimal PCR temperatures for amplification of the anammox 16S rRNA genes is presented in Table 2.

\section{Functional genes}

Although PCR amplification with 16S rRNA gene is widely used in anammox bacteria detection, the main pitfall of this molecular marker is that it is not necessarily restricted to the physiological group of anammox bacteria (Junier et al. 2010). Functional gene biomarker could also provide activity information in addition to the presence of anammox bacteria when quantitative reverse-transcriptionPCR is performed. Furthermore, PCR amplification for a unique functional gene target would mean a significant increase in the detection efficiency from samples with low anammox bacteria $(<1 \%)($ Kartal et al. 2011). Therefore, the recent progress in anammox bacterial genomics and biochemistry and physiology will identify reliable functional gene targets for such use.

Based on the anammox metabolism, four core catalytic proteins appear to be the most likely promising candidates for new PCR primer design: nitrite and nitrate reductases, hydrazine hydrolase, and hydrazine dehydrogenase (HZO) (Strous et al. 2006). Currently, the HZO, also called the hydroxylamine oxidoreductase-like protein (HAO), has the highest number of available sequences in the public database. More than ten primer sets are available for the PCR amplification of gene encoding this protein (Table 3). These primers target three different clusters of HAO/HZO proteins (Klotz et al. 2008; Schmid et al. 2008), but only hzo-cluster 1 with two copies in each genome is considered to be the most suitable biomarker for anammox bacteria phylogenetic analysis. Up to now, hzo gene has been successfully used to detect anammox bacteria from various environmental samples, including wastewater treatment plants (Quan et al. 2008; Li et al. 2009; Park et al. 2010), mangrove sediment (Li et al. 2010b, 2011a), estuaries (Li et al. 2011a; Hirsch et al. 2011), coastal and deep-ocean sediments (Dang et al. 2010; Hong et al. 2011a; Hirsch et al. 2011; Li et al. 2010b), hydrothermal vents (Hirsch et al. 2011), and oil reservoirs (Li et al. 2010a). These studies strongly indicated that the hzo gene could be a very competitive functional biomarker for anammox bacteria detection because higher resolution for the community structure of anammox bacteria than that by $16 \mathrm{~S}$ rRNA genes has been achieved ( $\mathrm{Li}$ et al. 2010b).

Another functional biomarker with application in anammox bacteria detection is the cd1 nitrite reductase (NIRS)

Table 2 List of PCR primers for the amplification the 16S rRNA genes of planctomycetes and anammox bacteria and the quantification of anammox bacteria

\begin{tabular}{|c|c|c|c|c|}
\hline Primer name & Sequences $5^{\prime}-3^{\prime}$ & Specificity group & Annealing $T\left({ }^{\circ} \mathrm{C}\right)$ & References \\
\hline $\mathrm{Pla} 46 \mathrm{~F}^{\mathrm{a}}$ & GACTTGCATGCCTAATCC & Planctomycetes & 58 & Neef et al. (1998) \\
\hline $\mathrm{Am} \times 368 \mathrm{~F}^{\mathrm{b}}$ & CCTTTCGGGCATTGCGAA & All anammox bacteria & 56 & Schmid et al. (2003) \\
\hline Brod $541 \mathrm{~F}$ & GAGCACGTAGGTGGGTTTGT & Scalindua sp. & 60 & Penton et al. (2006) \\
\hline $\mathrm{AMX} 809 \mathrm{~F}^{\mathrm{c}}$ & GCCGTAAACGATGGGCACT & Most anammox bacteria & 60 & Tsushima et al. (2007) \\
\hline $\mathrm{AMX} 818 \mathrm{~F}^{\mathrm{c}}$ & ATGGGCACTMRGTAGAGGGGTTT & Most anammox bacteria & 60 & Tsushima et al. (2007) \\
\hline Amx694F & GGGGAGAGTGGAACTTCGG & All anammox bacteria & 60 & Ni et al. (2010) \\
\hline Amx820R & AAAACCCCTCTACTTAGTGCCC & Brocadia and Kuenenia & 56 & Schmid et al. (2000) \\
\hline BS $820 \mathrm{R}$ & TAATTCCCTCTACTTAGTGCCC & Scalindua & 56 & Kuypers et al. (2003) \\
\hline Brod1260R & GGATTCGCTTCACCTCTCGG & Scalindua sp. & 60 & Penton et al. (2006) \\
\hline AMX1066 $\mathrm{R}^{\mathrm{c}}$ & AACGTCTCACGACACGAGCTG & Most anammox bacteria & 60 & Tsushima et al. (2007) \\
\hline$A m x 960 R^{c}$ & GCTCGCACAAGCGGTGGAGC & All anammox bacteria & 60 & Ni et al. (2010) \\
\hline
\end{tabular}

${ }^{a}$ Can be used as a forward primer with other reverse primers for PCR amplification of planctomycetes and anammox bacteria

${ }^{\mathrm{b}} \mathrm{Can}$ be used as a forward primer with other reverse primers for PCR amplification of anammox bacteria with higher specificity

${ }^{\mathrm{c}}$ Designed for quantitative real-time PCR 
Table 3 List of PCR primers for the amplification of functional genes of anammox bacteria

\begin{tabular}{|c|c|c|c|c|c|}
\hline Primer name & Sequences $5^{\prime}-3^{\prime}$ & Specificity group & Product size & $\begin{array}{l}\text { Annealing } \\
T\left({ }^{\circ} \mathrm{C}\right)\end{array}$ & References \\
\hline hzocl1F1 & TGYAAGACYTGYCAYTGG & hzo & 470 & 50 & Schmid et al. (2008) \\
\hline hzocl1R2 & ACTCCAGATRTGCTGACC & & & & \\
\hline hzocl1F & TGYAAGACYTGYCAYTGGG & hzo & 470 & 53 & Schmid et al. (2008) \\
\hline hzocl1R2 & ACTCCAGATRTGCTGACC & & & & \\
\hline hzocl $2 \mathrm{aF}$ & GGTTGYCACACAAGGC & hzo & 289 & 50 & Schmid et al. (2008) \\
\hline hzocl2aR1 & TYWACCTGGAACATACCC & & & & \\
\hline hzocl2aF1 & GGTTGYCACACAAGGC & hzo & 525 & 48 & Schmid et al. (2008) \\
\hline hzocl2aR2 & ATATTCACCATGYTTCCAG & & & & \\
\hline hzocl2aF2 & GTTGTGMTGMWTGTCATGG & hzo & 838 & 48 & Schmid et al. (2008) \\
\hline hzocl2aR1 & TYWACCTGGAACATACCC & & & & \\
\hline Ana-hzo1 & ACCTCTTCWGCAGGTGCAT & hzo & 1,000 & 53 & Quan et al. (2008) \\
\hline Ana-hzo2R & ACCTCTTCWGCAGGTGCAT & & & & \\
\hline hzoF1 & TGTGCATGGTCAATTGAAAG & hzo & 1,000 & 53 & Li et al. (2010b) \\
\hline hzoR1 & CAACCTCTTCWGCAGGTGCATG & & & & \\
\hline hzoAB1F & GAAGCNAAGGCNGTAGAAATTATCAC & hzo & 1,150 & 53 & Hirsch et al. (2011) \\
\hline hzoAB1R & CTCTTCNGCAGGTGCATGATG & & & & \\
\hline hzoAB4F & TTGARTGTGCATGGTCTAWTGAAAG & hzo & 600 & 55 & Hirsch et al. (2010) \\
\hline hzoAB4R & GCTGACCTGACCARTCAGG & & & & \\
\hline Scnir372F & TGTAGCCAGCATTGTAGCGT & Scalindua $n i r S$ & 473 & 60 & Lam et al. (2009) \\
\hline Scnir845R & TCAAGCCAGACCCATTTGCT & & & & \\
\hline AnnirS379F & TCTATCGTTGCATCGCATTT & $\begin{array}{l}\text { Anammox bacteria nirS (except } \\
\text { Scalindua nirS) }\end{array}$ & 442 & 51 & Li et al. (2011b) \\
\hline AnnirS821R & GGATGGGTCTTGATAAACA & & & & \\
\hline
\end{tabular}

gene, and a PCR primer set designed for the amplification of nirS gene of Candidatus "Scalindua sp." is available currently (Lam et al. 2009; Li et al. 2011b)(Table 3). With this primer set, the transcription levels of anammox nirS genes in the Peruvian upwelling zone were reported, correlating to activity rather than the presence of anammox bacteria alone in this area (Lam et al. 2009). In addition, results also indicated that these Scanlindua-nirS genes were fairly diverse, but all clustered with the nirS gene present in the Candidatus Scalindua genome assembly (73\%-93\% nucleotide sequence identity) and two sequences obtained from the Arabian Sea; however, they were clearly different from the typical denitrifiers' nirS genes $(<63 \%$ sequence identity), indicating that Scalindua-nirS can be a candidate functional gene biomarker for anammox in environmental samples (Lam et al. 2009; Li et al. 2011). Recently, a newly designed PCR primer set (AnnirS), together with the PCR primer (ScnirS), have been successfully used to detect anammox bacterial nirS genes from marine sediments, and results indicated that the ScnirS primer is specific for Scalindua nirS gene while AnnirS primer set is possibly specific for other genera of anammox bacterial nirS genes (Li et al. 2011b). The results further confirmed that the anammox bacterial nirS gene is a suitable functional biomarker for investigation of anammox bacteria in the environment ( $\mathrm{Li}$ et al. 2011b).

For the other two potential functional biomarkers, nitrate reductase and hydrazine hydrolase, no PCR primer is available at this moment due to the limited sequences available, thus further research opportunity is widely open in this direction.

\section{Quantitative PCR}

In addition to the FISH technique, qPCR, quantifying anammox bacterial 16S DNA or RNA gene copies, is also an effective and suitable method for the estimation of the anammox bacteria. Through the qPCR technique, anammox bacteria can be quantified in wastewater treatment reactors (Bae et al. 2010), marine oxygen minimum zones (Hamersley et al. 2007; Lam et al. 2009), and marine sediments (Li et al. 2010b, 2011a, 2011b; Brandsma et al. 2011). Furthermore, combining with the RT-PCR of the functional genes, such as hzo and Scalindua-nirS, the activity of anammox bacteria could also be assessed through the qPCR technique (Lam et al. 2009; Park et al. 2010). However, the abundance of anammox bacteria using qPCR technique might not match very well with the results of FISH counts (Brandsma et al. 2011). Reasons 
for this mismatch are due to different detection efficiencies with different probes used and primers for the various anammox species, such as detection cells by FISH can be a challenge because of detection limit while the qPCR reaction can be hampered by organic matter in the samples (Lindberg et al. 2007; Kallmeyer and Smith 2009; Brandsma et al. 2011). In spite of this uncertainty, qPCR, estimating anammox bacterial RNA or DNA gene abundance, is still an effective and powerful tool for quantification analysis of anammox bacteria.

\section{Summary}

Three different kinds of methods based on the physiological, biochemical characteristics of anammox bacteria are widely used in detecting anammox bacteria in natural and man-made ecosystems. IPT technique might be best choice for a proper evaluation of the contribution of anammox to the overall nitrogen removal, while the lipids analysis and molecular techniques would contribute more specifically to the presence and abundance of anammox bacteria in a particular habitat. In addition, molecular methods, using the 16S rRNA and functional genes as biomarkers, could further elucidate the anammox bacteria from the phylogenetic diversity to quantitative distribution in various samples. By combining ${ }^{15} \mathrm{~N}$ labeling, FISH, qPCR, RT-PCR, and ladderane lipid and IGP analysis simultaneously, anammox in a specific niche can be analyzed comprehensively and new information on anammox bacteria may be revealed. Therefore, these methods have contributed significantly to our present knowledge on its ecology, distribution, and phylogeny and on the revision of global nitrogen cycle. Future development of these techniques, especially on the most sensitive PCR-based molecular techniques, will certainly yield a more informative picture about anammox bacteria in the natural ecosystem.

Open Access This article is distributed under the terms of the Creative Commons Attribution Noncommercial License which permits any noncommercial use, distribution, and reproduction in any medium, provided the original author(s) and source are credited.

\section{References}

Amann RI, Krumholz L, Stahl DA (1990) Fluorescent-oligonucleotide probing of whole cells for determinative, phylogenetic, and environmental studies in microbiology. J Bacteriol 172:762-770

Amann RI, Ludwig W, Schleifer KH (1995) Phylogenetic identification and in situ detection of individual microbial cells without cultivation. Microbiol Rev 59:143-169

Bae H, Park K, Chung Y, Jung J (2010) Distribution of anammox bacteria in domestic WWTPs and their enrichments evaluated by real-time quantitative PCR. Process Biochem 45:323-334
Boumann HA, Hopmans EC, van de Leemput I, Camp HJM, van de Vossenberg J, Strous M, Jetten MSM, Sinninghe Damsté JS, Schouten S (2006) Ladderane phospholipids in anammox bacteria comprise phosphocholine and phosphoethanolamine headgroups. FEMS Microbiol Lett 258:297-304

Brandsma J, van de Vossenberg J, Risgaard-Petersen N, Schmid MC, Engstrom P, Eurenius K, Hulth S, Jaeschke A, Abbas B, Hopmans EC, Strous M, Schouten S, Jetten MSM, Sinninghe Damsté JS (2011) A multi-proxy study of anaerobic ammonium oxidation in marine sediments of the Gullmar Fjord, Sweden. Environ Microbiol Rep. doi:10.111/j.1758-2229.2010.00233.x

Bull ID, Parekh NR, Hall GH, Ineson P, Evershed RP (2000) Detection and classification of atmospheric methane oxidizing bacteria in soil. Nature 405:175-178

Byrne N, Strous M, Crepeau V, Kartal B, Birrien JL, Schmid M, Lesongeur F, Schouten S, Jaeschke A, Jetten M, Prieur D, Godfroy A (2009) Presence and activity of anaerobic ammonium-oxidizing bacteria at deep-sea hydrothermal vents. ISME J 3:117-123

Dalsgaard T, Thamdrup B (2002) Factors controlling anaerobic ammonium oxidation with nitrite in marine sediments. Appl Environ Microbiol 68:3802-3808

Dalsgaard T, Canfield DE, Petersen J, Thamdrup B, Acuna-Gonzalez J (2003) $\mathrm{N}_{2}$ production by the anammox reaction in the anoxic water column of Golfo Dulce, Costa Rica. Nature 422:606-608

Dalsgaard T, Thamdrup B, Canfield DE (2005) Anaerobic ammonium oxidation (anammox) in the marine environment. Res Microbiol $156: 457-464$

Daims H, Brühl A, Amann R, Schleifer KH, Wagner M (1999) The domain-specific probe EUB338 is insufficient for the detection of all bacteria: development and evaluation of a more comprehensive probe set. Syst Appl Microbiol 22:434-444

Dang H, Chen R, Wang L, Guo L, Chen P, Tang Z, Tian F, Li S, Klotz MG (2010) Environmental factors shape sediment anammox bacterial communities in hypernutrified Jiaozhou Bay, China. Appl Environ Microbiol 76:7036-7047

Davidsson TE, Stepanauskas R, Leonardson L (1997) Vertical patterns of nitrogen transformations during infiltration in two wetland soils. Appl Environ Microbiol 63:3648-3656

Devol AH (2003) Nitrogen cycle - solution to a marine mystery. Nature 422:575-576

Dong X, Tollner EW (2003) Evaluation of Anammox and denitrification during anaerobic digestion of poultry manure. Bioresour Technol 86:139-145

Francis CA, Beman JM, Kuypers MM (2007) New processes and players in the nitrogen cycle: the microbial ecology of anaerobic and archaeal ammonia oxidation. ISME J 1:19-27

Giovannoni SJ, Delong EF, Olsen GJ, Pace NR (1988) Phylogenetic group-specific oligodeoxynucleotide probes for identification of single microbial cells. J Bacteriol 170:720-726

Hamersley MR, Lavik G, Woebken D, Rattray JE, Lam P, Hopmans EC, Damsté JSS, Krüger S, Graco M, Gutierrez D, Kuypers MMM (2007) Anaerobic ammonium oxidation in the Peruvian oxygen minimum zone. Limnol Oceanogr 52:923-933

Hellinga C, Schellen AAJC, Mulder JW, van Loosdrecht MCM, Heijnen JJ (1998) The SHARON process: an innovative method for nitrogen removal from ammonium-rich waste water. Water Sci Technol 37(9):135-142

Hirsch MD, Long ZT, Song B (2011) Anammox bacterial diversity in various aquatic ecosystems based on the detection of hydrazine oxidase genes (hzoA/hzoB). Microb Ecol 61:264-267

Hong YG, Li M, Cao HL, Gu J-D (2011) Residence of habitat-specific anammox bacteria in the deep-sea subsurface sediments of South China Sea: analyses of maker gene abundance context with physicochemical parameters. Microb Ecol. doi:10.1007/s00248011-9849-0 
Hong YG, Yin B, Zheng TL (2011a) Diversity and abundance of anammox bacterial community in the deep-ocean surface sediment from equatorial Pacific. Appl Microbiol Biotechnol 89:1233-1241

Hopmans EC, Kienhuis MVM, Rattray JE, Jaeschke A, Schouten S, Damste JSS (2006) Improved analysis of ladderane lipids in biomass and sediments using high-performance liquid chromatography/atmospheric pressure chemical ionization tandem mass spectrometry. Rapid Commun Mass Spectrom 20:2099-2103

Hoshino T, Yilmaz LS, Noguera DR, Daims H, Wagner M (2008) Quantification of target molecules needed to detect microorganisms by fluorescence in situ hybridization (FISH) and catalyzed reporter deposition-FISH. Appl Environ Microbiol 74:5068-5077

Jaeschke A, Hopmans EC, Wakeham SG, Schouten S, Damste JSS (2007) The presence of ladderane lipids in the oxygen minimum zone of the Arabian Sea indicates nitrogen loss through anammox. Limnol Oceanogr 52:780-786

Jaeschke A, Rooks C, Trimmer M, Nicholls JC, Hopmans EC, Schouten S, Sinninghe Damsté JS (2009) Comparison of ladderane phospholipids and core lipids as indicators for anaerobic ammonium oxidation (anammox) in marine sediments. Geochim Cosmochim Acta 73:2077-2088

Jetten MSM, Schmid MC, Schmidt I, Wubben M, van Dongen U, Abma W, Sliekers AO, Revsbech NP, Beaumont HJE, Ottosen L, Volcke E, Laanbroek HJ, Campos Gomez JL, Cole JA, van Loosdrecht MCM, Mulder JW, Fuerst J, Richardson D, van de Pas-Schoonen KT, Mendez Pampin R, Third K, Cirpus K, van Spanning R, Bollmann A, Nielsen LP, Op den Camp HJM, Schultz JGC, Vanrolleghem P, Strous M, Wagner M, Kuenen JG (2002) Improved nitrogen removal by application of new nitrogen-cycle bacteria. Rev Environ Sci Biotechnol 1:51-63

Jetten MSM, Sliekers O, Kuypers M, Dalsgaard T, van Niftrik L, Cirpus I, van de Pas-Schoonen K, Lavik G, Thamdrup B, Le Paslier D, Op den Camp HJM, Hulth S, Nielsen LP, Abma W, Third K, Engstrom P, Kuenen JG, Jorgensen BB, Canfield DE, Damsté JSS, Revsbech NP, Fuerst J, Weissenbach J, Wagner M, Schmidt I, Schmid M, Strous M (2003) Anaerobic ammonium oxidation by marine and freshwater planctomycete-like bacteria. Appl Microbiol Biotechnol 63:107-114

Jetten M, Schmid M, van de Pas-Schoonen K, Sinninghe Damste J, Strous M (2005) Anammox organisms: enrichment, cultivation, and environmental analysis. Methods Enzymol 397:34-57

Jetten MS, Niftrik L, Strous M, Kartal B, Keltjens JT, Op den Camp HJ (2009) Biochemistry and molecular biology of anammox bacteria. Crit Rev Biochem Mol Biol 44:65-84

Junier P, Molina V, Dorador C, Hadas O, Kim OS, Junier T, Witzel JP, Imhoff JF (2010) Phylogenetic and functional marker genes to study ammonia-oxidizing microorganisms (AOM) in the environment. Appl Microbiol Biotechnol 85:425-440

Kallmeyer J, Smith DC (2009) An improved electro-elution method for separation of DNA from humic substances in marine sediment DNA extracts. FEMS Microbiol Ecol 69:125-131

Kartal B, Kuypers MM, Lavik G, Schalk J, Op den Camp HJ, Jetten MS, Strous M (2007a) Anammox bacteria disguised as denitrifiers: nitrate reduction to dinitrogen gas via nitrite and ammonium. Environ Microbiol 9:635-642

Kartal B, Rattray J, van Niftrik LA, van de Vossenberg J, Schmid MC, Webb RI, Schouten S, Fuerst JA, Damste JS, Jetten MS, Strous M (2007b) Candidatus "Anammoxoglobus propionicus" a new propionate oxidizing species of anaerobic ammonium oxidizing bacteria. Syst Appl Microbiol 30:39-49

Kartal B, van Niftrik L, Rattray J, van de Vossenberg JL, Schmid MC, Sinninghe Damste J, Jetten MS, Strous M (2008) Candidatus 'Brocadia fulgida': an autofluorescent anaerobic ammonium oxidizing bacterium. FEMS Microbiol Ecol 63:46-55
Kartal B, Geerts W, Jetten MS (2011) Cultivation, detection, and ecophysiology of anaerobic ammonium-oxidizing bacteria. Methods Enzymol 486:89-108

Klotz MG, Schmid MC, Strous M, Op den Camp HJ, Jetten MS, Hooper AB (2008) Evolution of an octahaem cytochrome c protein family that is key to aerobic and anaerobic ammonia oxidation by bacteria. Environ Microbiol 10:3150-3163

Kuai LP, Verstraete W (1998) Ammonium removal by the oxygenlimited autotrophic nitrification-denitrification system. Appl Environ Microbiol 64:4500-4506

Kubota K, Ohashi A, Imachi H, Harada H (2006) Improved in situ hybridization efficiency with locked-nucleic-acid-incorporated DNA probes. Appl Environ Microbiol 72:5311-5317

Kuenen JG (2008) Anammox bacteria: from discovery to application. Nat Rev Microbiol 6:320-326

Kumar M, Lin J-G (2010) Co-existence of anammox and denitrification for simultaneous nitrogen and carbon removal-strategies and issues. J Hazard Mater 178:1-9

Kuypers MM, Sliekers AO, Lavik G, Schmid M, Jorgensen BB, Kuenen JG, Sinninghe Damste JS, Srous M, Jetten MS (2003) Anaerobic ammonium oxidation by anammox bacteria in the Black Sea. Nature 422:608-611

Kuypers MM, Lavik G, Woebken D, Schmid M, Fuchs BM, Amann R, Jorgensen BB, Jetten MS (2005) Massive nitrogen loss from the Benguela upwelling system through anaerobic ammonium oxidation. Proc Natl Acad Sci USA 102:64786483

Lam P, Lavik G, Jensen MM, van de Vossenberg J, Schmid M, Woebken D, Gutierrez D, Amann R, Jetten MS, Kuypers MM (2009) Revising the nitrogen cycle in the Peruvian oxygen minimum zone. Proc Natl Acad Sci USA 106:4752-4757

Lee N, Nielsen PH, Andreasen KH, Juretschko S, Nielsen JL, Schleifer KH, Wagner M (1999) Combination of fluorescent in situ hybridization and microautoradiography - a new tool for structure-function analyses in microbial ecology. Appl Environ Microbiol 65:1289-1297

Li XR, Du B, Fu HX, Wang RF, Shi JH, Wang Y, Jetten MS, Quan ZX (2009) The bacterial diversity in an anaerobic ammoniumoxidizing (anammox) reactor community. Syst Appl Microbiol 32:278-289

Li H, Chen S, Mu BZ, Gu J-D (2010a) Molecular detection of anaerobic ammonium-oxidizing (anammox) bacteria in hightemperature petroleum reservoirs. Microb Ecol 60:771-783

Li M, Hong Y, Klotz MG, Gu J-D (2010b) A comparison of primer sets for detecting 16S rRNA and hydrazine oxidoreductase genes of anaerobic ammonium-oxidizing bacteria in marine sediments. Appl Microbiol Biotechnol 86:781-790

Li M, Cao H, Hong Y, Gu J-D (2011a) Seasonal dynamics of anammox bacteria in estuarial sediment of the Mai Po Nature Reserve revealed by analyzing the 16S rRNA and hydrazine oxidoreductase (hzo) genes. Microb Environ 26:15-22

Li M, Ford T, Li XY, Gu J-D (2011b) Cytochrome cd-1-containing nitrite encoding gene nirS as a new functional biomarker for detection of anaerobic ammonium oxidizing (Anammox) bacteria. Envion Sci Technol. doi:10.1021/es103826w

Lindberg E, Albrechtsen HJ, Jacobsen CS (2007) Inhibition of realtime PCR in DNA extracts from aquifer sediment. Geomicrobiol J 24:343-352

Moraru C, Lam P, Fuchs BM, Kuypers MM, Amann R (2010) GeneFISH - an in situ technique for linking gene presence and cell identity in environmental microorganisms. Environ Microbiol 12:3057-3073

Morgenroth E, Obermayer A, Arnold E, Brühl A, Wagner M, Wilderer PA (2000) Effect of long-term idle periods on the performance of sequencing batch reactors. Water Sci Technol 41:105-113 
Murrell JC, Whiteley A (2011) Stable isotope probing and related technologies. ASM, Washington

Neef A, Amann R, Schlesner H, Schleifer KH (1998) Monitoring a widespread bacterial group: in situ detection of planctomycetes with 16S rRNA-targeted probes. Microbiology 144:3257-3266

Ni BJ, Hu BL, Fang F, Xie WM, Kartal B, Liu XW, Sheng GP, Jetten M, Zheng P, Yu HQ (2010) Microbial and physicochemical characteristics of compact anaerobic ammonium-oxidizing granules in an upflow anaerobic sludge blanket reactor. Appl Environ Microbiol 76:2652-2656

Nielsen LP (1992) Denitrification in sediments determined from nitrogen isotope pairing. FEMS Microbiol Ecol 86:357-362

Park H, Rosenthal A, Ramalingam K, Fillos J, Chandran K (2010) Linking community profiles, gene expression and $\mathrm{N}$-removal in anammox bioreactors treating municipal anaerobic digestion reject water. Environ Sci Technol 44:6110-6116

Pavlekovic M, Schmid MC, Schmider-Poignee N, Spring S, Pilhofer M, Gaul T, Fiandaca M, Löffler FE, Jetten M, Schleifer KH, Lee NM (2009) Optimization of three FISH procedures for in situ detection of anaerobic ammonium oxidizing bacteria in biological wastewater treatment. J Microbiol Methods 78:119-126

Penton CR, Devol AH, Tiedje JM (2006) Molecular evidence for the broad distribution of anaerobic ammonium-oxidizing bacteria in freshwater and marine sediments. Appl Environ Microbiol 72:6829-6832

Pernthaler A, Pernthaler J, Amann R (2002) Fluorescence in situ hybridization and catalyzed reporter deposition for the identification of marine bacteria. Appl Environ Microbiol 68:3094-3101

Perry-O'Keefe H, Rigby S, Oliveira K, Sorensen D, Stender H, Coull J, Hyldig-Nielsen JJ (2001) Identification of indicator microorganisms using a standardized PNA FISH method. J Microbiol Methods 47:281-292

Pind A, Risgaard-Petersen N, Revsbech NP (1997) Denitrification and microphytobenthic $\mathrm{NO}_{3}{ }^{-}$consumption in a Danish lowland stream: diurnal and seasonal variation. Aquat Microb Ecol 12:275-284

Poulsen LK, Ballard G, Stahl DA (1993) Use of rRNA fluorescence in situ hybridization for measuring the activity of single cells in young and established biofilms. Appl Environ Microbiol 59:1354-1360

Pratscher J, Dumont MG, Conrad R (2011) Ammonia oxidation coupled to $\mathrm{CO}_{2}$ fixation by archaea and bacteria in an agricultural soil. Proc Natl Acad Sci USA. doi:10.1073/pnas.1010981108

Quan ZX, Rhee SK, Zuo JE, Yang Y, Bae JW, Park JR, Lee ST, Park YH (2008) Diversity of ammonium-oxidizing bacteria in a granular sludge anaerobic ammonium-oxidizing (anammox) reactor. Environ Microbiol 10:3130-3139

Risgaard-Petersen N (2003) Coupled nitrification-denitrification in autotrophic and heterotrophic estuarine sediments: on the influence of benthic microalgae. Limnol Oceanogr 48:93-105

Risgaard-Petersen N, Nielsen LP, Rysgaard S, Dalsgaard T, Meyer RL (2003) Application of the isotope pairing technique in sediments where anammox and denitrification coexist. Limnol Oceanogr: Methods 1:63-73

Risgaard-Petersen N, Meyer RL, Schmid M, Jetten MSM, Enrich-Prast A, Rysgaard S, Revsbech NP (2004) Anaerobic ammonium oxidation in an estuarine sediment. Aquat Microb Ecol 36:293-304

Rysgaard S, Glud RN (2004) Anaerobic $\mathrm{N}_{2}$ production in Arctic sea ice. Limnol Oceanogr 49:86-94

Rysgaard S, Risgaard-Petersen N, Nielsen LP, Revsbech NP (1993) Nitrification and denitrification in lake and estuarine sediments measured by the ${ }^{15} \mathrm{~N}$ dilution technique and isotope pairing. Appl Environ Microbiol 59:2093-2098

Rysgaard S, Glud RN, Risgaard-Petersen N, Dalsgaard T (2004) Denitrification and anammox activity in Arctic marine sediments. Limnol Oceanogr 49:1493-1502
Schmid M, Twachtmann U, Klein M, Strous M, Juretschko S, Jetten M, Metzger JW, Schleifer KH, Wagner M (2000) Molecular evidence for genus level diversity of bacteria capable of catalyzing anaerobic ammonium oxidation. Syst Appl Microbiol 23:93-106

Schmid M, Schmitz-Esser S, Jetten M, Wagner M (2001) 16S-23S rDNA intergenic spacer and 23S rDNA of anaerobic ammoniumoxidizing bacteria: implications for phylogeny and in situ detection. Environ Microbiol 3:450-459

Schmid M, Walsh K, Webb R, Rijpstra WIC, van de Pas-Schoonen K, Verbruggen MJ, Hill T, Moffett B, Fuerst J, Schouten S, Damste JSS, Harris J, Shaw P, Jetten M, Strous M (2003) Candidatus "Scalindua brodae", sp. nov., Candidatus "Scalindua wagneri", sp. nov., two new species of anaerobic ammonium oxidizing bacteria. Syst Appl Microbiol 26:529-538

Schmid MC, Maas B, Dapena A, van de Pas-Schoonen K, van de Vossenberg J, Kartal B, van Niftrik L, Schmidt I, Cirpus I, Kuenen JG, Wagner M, Sinninghe Damste JS, Kuypers M, Revsbech NP, Mendez R, Jetten MS, Strous M (2005) Biomarkers for in situ detection of anaerobic ammonium-oxidizing (anammox) bacteria. Appl Environ Microbiol 71:1677-1684

Schmid MC, Risgaard-Petersen N, van de Vossenberg J, Kuypers MMM, Lavik G, Petersen J, Hulth S, Thamdrup B, Canfield D, Dalsgaard T, Rysgaard S, Sejr MK, Strous M, den Camp HJ, Jetten MS (2007) Anaerobic ammonium-oxidizing bacteria in marine environments: widespread occurrence but low diversity. Environ Microbiol 9:1476-1484

Schmid MC, Hooper AB, Klotz MG, Woebken D, Lam P, Kuypers MM, Pommerening-Roeser A, Op den Camp HJ, Jetten MS (2008) Environmental detection of octahaem cytochrome c hydroxylamine/ hydrazine oxidoreductase genes of aerobic and anaerobic ammonium-oxidizing bacteria. Environ Microbiol 10:3140-3149

Schubert CJ, Durisch-Kaiser E, Wehrli B, Thamdrup B, Lam P, Kuypers MM (2006) Anaerobic ammonium oxidation in a tropical freshwater system (Lake Tanganyika). Environ Microbiol 8:1857-1863

Sinninghe Damste JS, Strous M, Rijpstra WI, Hopmans EC, Geenevasen JA, van Duin AC, van Niftrik LA, Jetten MS (2002) Linearly concatenated cyclobutane lipids form a dense bacterial membrane. Nature 419:708-712

Sinninghe Damste JS, Rijpstra WI, Geenevasen JA, Strous M, Jetten MS (2005) Structural identification of ladderane and other membrane lipids of planctomycetes capable of anaerobic ammonium oxidation (anammox). FEBS J 272:4270-4283

Sliekers AO, Derwort N, Gomez JL, Strous M, Kuenen JG, Jetten MS (2002) Completely autotrophic nitrogen removal over nitrite in one single reactor. Water Res 36:2475-2482

Stepanauskas R, Davidsson ET, Leonardson L (1996) Nitrogen transformations in wetland soil cores measured by ${ }^{15} \mathrm{~N}$ isotope pairing and dilution at four infiltration rates. Appl Environ Microbiol 62:2345-2351

Strous M, Heijnen JJ, Kuenen JG, Jetten MSM (1998) The sequencing batch reactor as a powerful tool for the study of slowly growing anaerobic ammonium-oxidizing microorganisms. Appl Microbiol Biotechnol 50:589-596

Strous M, Fuerst JA, Kramer EH, Logemann S, Muyzer G, van de Pas-Schoonen KT, Webb R, Kuenen JG, Jetten MS (1999) Missing lithotroph identified as new planctomycete. Nature 400:446-449

Strous M, Pelletier E, Mangenot S, Rattei T, Lehner A, Taylor MW, Horn M, Daims H, Bartol-Mavel D, Wincker P, Barbe V, Fonknechten N, Vallenet D, Segurens B, Schenowitz-Truong C, Medigue C, Collingro A, Snel B, Dutilh BE, Op den Camp HJ, van der Drift C, Cirpus I, van de Pas-Schoonen KT, Harhangi HR, van Niftrik L, Schmid M, Keltjens J, van de Vossenberg J, Kartal B, Meier H, Frishman D, Huynen MA, Mewes HW, Weissenbach J, Jetten MS, Wagner M, Le Paslier D (2006) 
Deciphering the evolution and metabolism of an anammox bacterium from a community genome. Nature 440:790-794

Tal Y, Watts JE, Schreier HJ (2005) Anaerobic ammonia-oxidizing bacteria and related activity in Baltimore inner harbor sediment. Appl Environ Microbiol 71:1816-1821

Thamdrup B, Dalsgaard T (2002) Production of $\mathrm{N}_{2}$ through anaerobic ammonium oxidation coupled to nitrate reduction in marine sediments. Appl Environ Microbiol 68:1312-1318

Third KA, Sliekers AO, Kuenen JG, Jetten MS (2001) The CANON system (completely autotrophic nitrogen-removal over nitrite) under ammonium limitation: interaction and competition between three groups of bacteria. Syst Appl Microbiol 24:588-596

Tourna M, Ereitag TE, Prosser JI (2010) Stabke isotope probing analysis of interactions between ammonia oxidizers. Appl Environ Microbiol 76:2468-2477

Trimmer M, Nicholls JC, Deflandre B (2003) Anaerobic ammonium oxidation measured in sediments along the Thames estuary, United Kingdom. Appl Environ Microbiol 69:6447-6454

Trimmer M, Nicholls JC, Morley N, Davies CA, Aldridge J (2005) Biphasic behavior of anammox regulated by nitrite and nitrate in an estuarine sediment. Appl Environ Microbiol 71:1923-1930

Tsushima I, Kindaichi T, Okabe S (2007) Quantification of anaerobic ammonium- oxidizing bacteria in enrichment cultures by realtime PCR. Water Res 41:785-794

van de Graaf AA, Mulder A, de Bruijn P, Jetten MS, Robertson LA, Kuenen JG (1995) Anaerobic oxidation of ammonium is a biologically mediated process. Appl Environ Microbiol 61:12461251

van de Vossenberg J, Rattray JE, Geerts W, Kartal B, van Niftrik L, van Donselaar EG, Sinninghe Damste JS, Strous M, Jetten MS (2008) Enrichment and characterization of marine anammox bacteria associated with global nitrogen gas production. Environ Microbiol 10:3210-3219

van Niftrik LA, Fuerst JA, Sinninghe Damste JS, Kuenen JG, Jetten MS, Strous M (2004) The anammoxosome: an intracytoplasmic compartment in anammox bacteria. FEMS Microbiol Lett 233:7-13

Wagner M, Rath G, Amann R, Koops H-P, Schleifer K-H (1995) In situ identification of ammonia oxidizing bacteria. Syst Appl Microbiol 18:251-264

Ward BB, Devol AH, Rich JJ, Chang BX, Bulow SE, Naik H, Pratihary A, Jayakumar A (2009) Denitrification as the dominant nitrogen loss process in the Arabian Sea. Nature 461:78-81

Zhang LM, Offre PR, He J-H, Verhamme DT, Nicol GW, Prosser JI (2011) Autotrophic ammonia oxidation by soil thaumarchaea. Proc Natl Acad Sci USA 107:17240-17245

Zhu G, Jetten MS, Kuschk P, Ettwig KF, Yin C (2010) Potential roles of anaerobic ammonium and methane oxidation in the nitrogen cycle of wetland ecosystems. Appl Microbiol Biotechnol 86:1043-1055

Zwirglmaier K (2005) Fluorescence in situ hybridisation (FISH) - the next generation. FEMS Microbiol Lett 246:151-158 